Revista Vernáculo, nº 14 - 15 - 16, pp. 65 - 86.

\title{
A Inevitabilidade do Sintoma
}

\author{
Caio Cundari ${ }^{1}$ \\ Misery's the river of \\ the world \\ Everybody row \\ Everybody row, \\ everybody row \\ (Tom Waits, Misery's \\ the River of the World)
}

Resumo: $\mathrm{O}$ presente trabalho consiste em uma apresentação do sintoma e sua relação com a neurose, desde a obra freudiana. Percorre um caminho que vai desde os caminhos da libido até sua regressão e consequente recalque. $\mathrm{O}$ trabalho abrange os dois lados em conflito representados na formação do sintoma, constituído como um acordo entre a libido insatisfeita e a angústia de castração sentida pelo ego e que faz agir o recalque. Faz verificar que o sintoma é de fato inevitável, observação calcada na inevitabilidade do complexo de castração, na insuportabilidade da castração, cujo sintoma é constituído no sentido de mitigá-la, de fazê-la sumir.

Palavras chave: sintoma, recalque, angústia, castração.

\section{INTRODUÇÃO}

O presente trabalho terá por tema o sintoma e sua importância para o neurótico. Para que faça possível esclarecer de que maneira este se constitui como uma questão de pesquisa passível de nortear um trabalho dessa natureza, essa introdução tomará como referência algumas considerações freudianas acerca do sintoma, as quais apresento:

"Os sintomas - e, naturalmente agora estamos tratando de sintomas psíquicos (ou psicogênicos) e de doença psíquica - são atos prejudiciais, ou pelo menos, inúteis à vida da pessoa, que por vezes, deles se queixa como sendo indesejados e causadores de desprazer e sofrimento." (Freud, "Os Caminhos da Formação dos Sintomas", 1916, p. 25)

\footnotetext{
${ }^{1}$ Graduado em Psicologia pela UFPR.
} 
Com o presente parágrafo, introdutório do texto em questão, Freud aponta quais sejam as características mais evidentes dos sintomas psíquicos. Reconhece também que os pacientes que à clínica acedem se queixam de seus sintomas, afirmam lá estar em função de seus sintomas e do sofrimento que estes lhe causam em sua vida útil, e dos quais querem livrar-se. Também Freud afirma que a formação de sintomas implica em um importante dispêndio de energia, e ainda uma carga adicional se faz necessário para combatê-los. Destarte, uma extensa formação de sintomas resulta em um relevante empobrecimento de energia para o neurótico, o qual se vê paralisado para as tarefas importantes de sua vida e que lhe demandam investimento.

Não obstante, parece representar o sintoma ao ego uma produção de inegável importância. Este está envolvido na formação do sintoma e o apóia contra qualquer esforço no sentido de removê-lo ou descacterizá-lo.

“Já demonstrei que os sintomas também são apoiados pelo ego, porque possuem um aspecto com o qual oferecem satisfação ao propósito de recalque do ego. Ademais, apaziguar um conflito construindo um sintoma é a solução mais conveniente e mais agradável para o princípio de prazer: inquestionavelmente, poupa ao ego uma grande quantidade de trabalho interno que é sentido como penoso. (Freud, "O Estado Neurótico Comum”, 1916, p. 51)

Não se encerra por aí isso que se apresenta como uma dicotomia acerca do sintoma. Afirma Freud que um processo de análise tem por ponto de partida a análise do sintoma e suas precondições de formação, e é para se livrar dos tais sintomas é que, supostamente, o paciente procura o tratamento. Afirma porém que o sintoma ganha sua resistência em análise pelo que representa ao neurótico, por se constituir como uma acordo entre duas forças em oposição.

A contradição posta acima se nos faz motivo de estranheza, esse constitui como uma questão importante o suficiente para merecer ser o tema mesmo desse trabalho. Isto posto, se faz necessário uma definição mais aprofundada do sintoma - bem como do acordo que este representa - para que se faça possível apresentar a pergunta que orienta esse trabalho e o caminho realizado com base na obra freudiana para o apontamento de respostas.

Apenas uma apresentação bastante superficial foi feita do sintoma até o presente momento. O que foi então apresentado é o conflito entre duas forças antagônicas, igualmente representados em uma formação especial que se constitui como um acordo - o sintoma. Mas quais são essas forças? O que as faz serem forçosamente representadas em uma formação tal qual o sintoma, o qual provoca tamanho desprazer, e do qual tanto se queixa? 
Uma dessas forças é a libido que tem por força imperativa satisfazer-se. A outra, que se lhe opõe, Freud a apresenta, como o princípio de realidade que sobre o sujeito incide com todo o peso que lhe é característico, dado trazer o estigma da impossibilidade. A saída possível é aquela libido procurar vias alternativas de satisfação, adotar outros objetos que o interditado. Se mesmo os caminhos e objetos substitutos não corresponderem ao aceitável perante essa força que lhe faz oposição, esta libido tomará vias regressivas, e a partir dos pontos de fixação da libido adotará vias de satisfação em organizações e objetos anteriormente abandonados e novamente retomados como saída possível. Nesse sentido, a libido abandonará o objeto externo e retornará ao próprio corpo, ao que as fantasias serão de inegável importância nesse caminho regressivo da libido.

"Descobrimos, há algum tempo, que os neuróticos estão ancorados em algum ponto do seu passado; agora sabemos que esse ponto é um período do seu passado, no qual sua libido não se privava de satisfação, no qual eram felizes. Buscam na história de sua vida, até encontrarem um período dessa ordem, ainda que tenham de retroceder tanto que atinjam a época em que eram bebês de colo tal como dela se lembram ou imaginam, a partir de indícios posteriores." (Freud, "Os Caminhos da formação dos Sintomas", 1916, p. 33)

Ao investir em fantasias de natureza masturbatória abandonadas no percurso do desenvolvimento da libido atraem a atenção do recalque, ao direcionar regressivamente a libido às posições reprimidas a faz adentrar no campo do inconsciente, e se faz portanto sujeito às leis do inconsciente e seus processos.

Esses processos responsáveis pela manutenção do aparelho psíquico, sobretudo a condensação e o deslocamento, sob cuja égide estarão as vias de satisfação da libido no inconsciente, caracterizarão a libido reprimida e suas vias. Não obstante, a catexização desses pontos de fixação que haviam merecido recalque no passado faz com que se volte a atenção da mesma força novamente para o que passa a ser os representantes da libido no inconsciente, e age sobre a libido como uma anticatexia, exigindo da representação da libido que esta assuma a forma de nada menos que sua oposição.

O resultado dessa epopéia da libido é que ela alcançará satisfação de qualquer forma, mas de maneira tão restrita e desviada que mal se pode reconhecê-la, será a expressão da contradição e das muitas distorções sofridas em seu chamado caminho, que é mais percalço que caminho próprio. Assim está constituído o sintoma, resultado de um péssimo acordo, do ponto de vista pragmático, entre a libido e algo que se lhe interpõe, que Freud faz chamar "a 
realidade". Mas se se constitui como um péssimo negócio, porque afinal ele se realiza inevitavelmente, universalmente, como inerente à estruturação da neurose?

É indubitável que o sintoma é de valor inestimável para o neurótico, que a ele se apega acirradamente, ainda que dele se queixe, ao que Freud afirma que o sintoma ganha sua resistência, em um processo de análise, por ser apoiado pelos dois lados em conflito. Também não se trata de tomar partido por seja qual lado for, mas creio não se poder negar a um neófito o direito de se ver tomado por um profundo sentimento de estranheza frente a importância do sintoma para a neurose. É, de fato, o sintoma inevitável? Se o é, o que o faz sê-lo? O que tem em sua natureza, e o que passa a representar diante da neurose que lhe poderia sustentar nesse lugar de importância?

Este trabalho parte de um ponto, de que o sintoma se constitui como de fundamental importância a o decurso da vida do neurótico, ao que se faz possível compreender que também assim o é para uma prática clínica. Considera que o sintoma é apresentado como uma produção relacionada à própria constituição da neurose, ao que se faz igualmente possível considerar que é através da análise do sintoma que se faz possível inaugurar uma análise propriamente. Em um processo em que a condução do tratamento que faz direcionar a fala do paciente de um lugar de queixa até um reconhecimento que opera em si uma construção fantástica, que é disso que se queixa, e pela importância que tem em sua vida e suas escolhas isso muito lhe interessa, o sintoma entra na ordem do dia como um tema de estudo que, posto, creio oferecer maior sustentação para um início de relação à prática clínica.

Para ser possível extrair desse trabalho um ensaio de resposta para a pergunta que o norteia, creio se fazer fundamental percorrer alguns passos. Dessa maneira, primeiramente tomaremos o sintoma em sua caracterização, para depois tomá-lo em sua formação.

\section{1 - O SINTOMA}

Desde "O Caminho de Formação dos Sintomas", de 1916, Os sintomas são apresentados por Freud, antes de qualquer coisa, como atos prejudiciais, inúteis a quem os tem, causadores de desprazer e sofrimento. Faz-se necessário, dada sua universalidade, apresentar sua importância, suas condições e caminhos para sua formação, bem como as condições para que assuma essa forma aparentemente desprazerosa.

A primeira questão apresentada quanto aos sintomas é relativa ao dispêndio de energia que representa. Segundo Freud, o principal dano que o 
sintoma causa é em função de representar uma quantidade de energia direcionada constantemente para a manutenção desse sintoma, e ainda uma quantidade adicional de energia direcionada à manutenção de uma oposição a esse sintoma. Destarte, uma extensa formação de sintomas, Freud coloca, resultará em um importante empobrecimento da pessoa em relação à sua energia psíquica. Se observará, então, uma paralisação da pessoa em relação às suas atividades, decorrente do redirecionamento de energia, dantes investida nas atividades correntes da pessoa, para a manutenção do conflito representado pelo sintoma.

Em "O Sentido dos Sintomas", de 1916, Freud toma como exemplo dois casos que teve a oportunidade de atender para ilustrar aspectos relevantes referentes ao liame simbólico dos sintomas. Deve-se entender que adotar os mesmos casos de maneira a exemplificar a questão seria uma extrapolação dos objetivos desse trabalho, mas apresentar as conclusões de Freud é, sem dúvida, bastante pertinente. $\mathrm{O}$ que Freud retira destes pontos importantes acerca dos sintomas, é que estes apresentam, primeiramente, um simbolismo particular que dá sentido ao sintoma, ainda que este seja um sentido obscuro, criptografado. Estrutura-se o sintoma, então, meio que à maneira de um sonho, representando de uma maneira simbólica um desejo insatisfeito através de um simbolismo, uma referência ao desejo insatisfeito. É de fundamental relevância observar, igualmente que os sintomas neuróticos produzidos não representam um desejo qualquer, mas um desejo sexual insatisfeito. Os sintomas representam a vida sexual do neurótico, ao menos uma parte significativa de sua vida sexual.

Fica sugerido, desde os parágrafos anteriores, que há algo no sintoma que é representado, e que excede mesmo ao sofrimento inerente que muito lhe caracteriza. O que constitui o sintoma, então? O sintoma é constituído como um acordo entre a libido, cuja finalidade única é satisfazer-se, e uma força contrária que se lhe interpõe. Deixando de lado um pouco essa força de oposição constituída à libido, representada igualmente na constituição do sintoma, cabe um imiscuir-se à essa libido e seus caminho de satisfação até a constituição do sintoma propriamente. Em "Dois Verbetes de Enciclopédia", de 1923, especificamente no capítulo referente à teoria da libido, esta é descrita como a expressão dinâmica da sexualidade. O que se está tratando, portanto, quando se aborda a questão do sintoma, é deste como a expressão sexual do neurótico, em algum grau de importância. O sintoma representa para o neurótico uma satisfação sexual, ainda que parcial e distorcida.

Considerando que, na constituição do sintoma, o que está posto é a expressão própria da libido, da expressão dinâmica da sexualidade, faz-se necessário tomar o conceito de pulsão sexual para compreender a natureza da força que está em jogo no conflito referido originador do sintoma, bem como os 
caminhos que se lhe configuram como possibilidades de satisfação. Em "A Pulsão e seus Destinos" de 1915, Freud os especifica claramente. A pulsão, para Freud, é um conceito que se situa entre a esfera psíquica e a somática, e caracteriza-se por ser uma representação psíquica dos estímulos internos que atuam sobre o corpo. Tem sua própria origem nos estímulos internos ao organismo, e é uma força constante em sua natureza, constantemente premente.

Freud entende que a pulsão possui algumas qualidades particulares, as quais denomina perentoriedade, finalidade, objeto e fonte. Não sendo a conceituação pormenorizada da pulsão nosso objetivo neste trabalho, apenas nos interessa com isso afirmar que a pulsão é constante, e que sua única finalidade é a satisfação, assuma esta qual forma assumir. Quanto ao objeto da pulsão, este representa o instrumento pelo qual a pulsão atingirá sua satisfação e é da natureza da relação da pulsão ao objeto ser variável. A pulsão é originariamente independente do objeto, e liga-se a este na medida exclusiva em que este lhe serve a uma satisfação. A pulsão pode tomar como objeto o próprio corpo, ou partes dele, e substituí-los indefinidamente, enquanto necessário à sua finalidade. Pode ainda encontrar-se irremediavelmente ligado a um objeto, processo denominado fixação da pulsão. Sobre isso Freud diz:

\begin{abstract}
"Quando uma pulsão aparece ligada de um modo especialmente íntimo e estreito ao objeto, fala-se em uma fixação da citada pulsão. Esta fixação efetua-se com grande freqüência em períodos muito precoces do desenvolvimento das pulsões e põe fim à mobilidade da pulsão referida, opondo-se intensamente a sua separação do objeto.” (Freud, “A Pulsão e seus Destinos”, 1915, p. 406)
\end{abstract}

O que nos interessa abarcar acerca das pulsões sexuais é que estas são numerosas, originadas em diversas fontes, e que agem sobre o sujeito originalmente independentemente. Afirma que há um processo de articulação subsequente dessas pulsões rumo a uma síntese, que se dará com maior ou menor sucesso.

Em "Três Ensaios sobre a Teoria da Sexualidade" de 1905, Freud aponta o que é essa organização particular que se dá pela articulação dessas pulsões sexuais parciais com a hegemonia da genitalidade. Ao expor os diversos objetos que a pulsão sexual toma no próprio corpo, bem como os diferentes caminhos que esta toma para alcançar satisfação, se permite concluir que as pulsões sexuais sejam compostas de diversos componentes reunidos em uma organização posterior, e que se o fazem é em função de forças anímicas que se lhe interpõem como resistências (tais quais vergonha e asco), e que atuam no sentido de organizá-las dentro de limites considerados normais. 
Apresenta-se como necessário, neste caminho pretendido de compreender o sintoma e sua relação com a estruturação das neuroses, uma análise pormenorizada do desenvolvimento da libido e suas fases de organização, até sua forma final. A libido, desta maneira, revela-se como uma estrutura altamente complexa e mutável, pois que é composta de uma grande quantidade de pulsões sexuais parciais, com fontes, objetivos e objetos diferentes por natureza. É uma organização instável e mutável por ser composta de uma articulação de pulsões que tendem a se desagregarem conforme seus destinos.

Para tanto é importante considerar a característica da vida sexual infantil. Freud a descreve como anárquica, as pulsões sexuais parciais componentes da libido alcançam satisfação de maneira variada e independente entre si. Há, porém, no decurso do desenvolvimento da libido, organizações particulares dessas pulsões, sob a primazia de um circuito particular de satisfação e de representação da vida sexual.

Pode-se afirmar, portanto, que o que se trata quando se aborda a questão da formação de sintomas neuróticos, assim como se fala da própria causação das neuroses, é o desenvolvimento da função da libido até sua organização final. Em seu tortuoso caminho, Freud afirma, nem todas as fases de organização da libido são abandonadas completa e permanentemente, são desinvestidas apenas parcialmente, permanecendo atuantes ao longo de seu desenvolvimento.

A apresentação do desenvolvimento dinâmico da libido abre espaço para a consideração detalhada de dois conceitos associados não apenas em si, mas também ao até então exposto. Em "Algumas Idéias sobre Desenvolvimento e Regressão - Etiologia", de 1916, Freud expõe o caminho da libido frustrada de maneira pormenorizada, a partir dos conceitos de fixação e regressão. $\mathrm{O}$ ponto de partida da consideração de Freud é que o desenvolvimento da libido não é linear, que é marcado por "percalços", como as fases já descritas, e que isso será decisivo na estruturação da neurose.

"Isto é, em vista da tendência geral dos processos biológicos à variação, não há como fugir ao fato de que nem todas as fases preparatórias são ultrapassadas com igual êxito e superadas completamente: partes da função serão retidas permanentemente nesses estádios iniciais e o quadro total do desenvolvimento será limitado por determinada quantidade de inibição de desenvolvimento." (Freud, "Algumas Idéias sobre Desenvolvimento e Regressão - Etiologia", 1916, pág 397)

Vê-se, portanto que há uma relação estreita entre a etiologia das neuroses e as fases de organização da libido. Freud entende que tais fases de organização 
não são inteiramente abandonadas no decurso do desenvolvimento. São grandemente catexizadas enquanto ativas, constituem-se como marcas psíquicas indeléveis para o neurótico, e à medida que a libido segue seu percurso, parte sua componente permanece ligada à tendência anterior. Essa ligação de uma parte componente da libido a uma tendência abandonada pela libido como estrutura é o que Freud denomina fixação da pulsão.

A fixação da pulsão ao longo do desenvolvimento libidinal representa aspecto relevante na originação da neurose por dois motivos que agem coadunados. Não apenas representam uma desagregação da energia sexual que se vê diminuída com a permanência de parte sua fixada à tendência abandonada, como constitui-se como ponto de referência para a libido frustrada em sua finalidade e que tende a buscar satisfação em organizações abandonadas como saída para a restrição que se lhe impõe. Essa retomada da libido por organizações parcialmente abandonadas, esse reinvestimento de energia nesses pontos de fixação como saída à frustração de sua finalidade, que é de satisfazer-se, Freud denomina regressão da libido. Sobre o conceito de regressão e sua relação com a fixação da pulsão, Freud diz:

"O segundo perigo em um desenvolvimento por etapas desse tipo reside no fato de que as partes que prosseguiram adiante podem também, com facilidade, retornar retrocessivamente a um desses estádios precedentes - o que descrevemos como regressão. A tendência ver-se-á conduzida a uma regressão desse tipo, se o exercício de sua função - isto é, a obtenção do seu objetivo de satisfação - depara, em sua forma posterior ou mais altamente desenvolvida, com poderosos obstáculos externos." (Freud, "Algumas Idéias sobre Desenvolvimento e Regressão - Etiologia”, 1916, pág. 399)

De que maneira se pode pensar em articular os conceitos expostos e afirmados como constituintes na formação dos sintomas? Há na história de todo neurótico, na própria etiologia das neuroses, um caminho de desenvolvimento da libido. Essa libido é composta por uma série de "tendências", como coloca Freud, por pulsões sexuais parciais as quais apresentam como fontes processos orgânicos distintos. Também são distintos seus objetos originais através de cujo investimento obtém satisfação. A libido é, portanto, originalmente desorganizada e multiforme enquanto expressão. No caminho de desenvolvimento já mencionado, essa característica infantil da libido é, em alguns momentos muito particulares, abandonada em um ensaio de organização da libido com a primazia de um circuito de satisfação em torno do qual as outras tendências são articuladas. Além da própria organização genital, há as organizações denominadas prégenitais, a oral e a sádico-anal, como já descrito anteriormente. Essas 
organizações anteriores, comparadas à guarnições por Freud, são altamente catexizadas por determinado período da vida do neurótico, pois que recebe a carga total da libido convergida, e no decurso do desenvolvimento da libido, tais organizações são apenas parcialmente desinvestidas. A parte que permanece como investimento à essa organização da libido já abandonada, que permanece fixada ao objeto correspondente à essa organização particular, caracterizará o que se passou a entender como pontos de fixação.

Não obstante, a libido segue seu caminho, e a subtração de energia representada pela fixação de uma parte componente de sua expressão total parece, a princípio, não lhe fazer sentir, ou pelo menos tardar-lhe em seu percurso. A partir da organização genital, e às voltas com a frustração posta que a diferença representa, a libido tende a buscar caminho alternativos de satisfação que lhe possam substituir. Cabe, entretanto, lembrar novamente que as pulsões possuem como finalidade única e inescapável a de satisfazer-se, ao que se coloca um percalço no caminho da libido. Interditada pela realidade intransigente, as fixações passam a representar, a posteriori, seu papel de importância na estruturação dinâmica do sintoma, pois que acenam ao conjunto da libido de si desvencilhada com a possibilidade reminiscente de satisfação. Destarte, a regressão que constitui o caminho da libido frustrada perante a realidade sustentase não apenas pela possibilidade de satisfação que acena, conforme já dito, mas também em função da subtração que a fixação representa para o total da libido colocar-se como um enfraquecimento desta perante os percalços que se lhe interpuserem. De qualquer maneira, e ao que afirma Freud, a libido adotará vias regressivas, tornará a catexizar pontos anteriores do desenvolvimento já abandonados, seja apenas uma regressão à objetos incestuosos, como na histeria, seja uma regressão à objetos incestuosos e à organizações anteriores (a sádicoanal, por exemplo), como na neurose obsessiva.

Neste presente momento, faz-se evidente que o esforço feito no sentido de relacionar os conceitos abordados até então não é suficiente para esgotar a questão pretendida como tema central desse trabalho, não bastam para explicitar todo o caminho de formação dos sintomas. Qual é a relação da construção teórica apresentada com a formação de sintomas? Ao analisar os aspectos concernentes à vida pulsional nas neuroses, faz observar que os sintomas que representam seu caráter patológico tem em sua base as pulsões sexuais. Mais, são sustentados pela energia que a pulsão sexual representa. Os sintomas são, portanto, efetivamente, a expressão sexual do neurótico em algum grau de importância. Afirma que, colocado o sujeito em uma posição de conflito, representado por um lado por uma premência sexual desenvolvida, e por outro, por um significativo recalcamento sexual, e pressionado pela pulsão sexual que demanda satisfação constantemente, 
apenas lhe resta enquanto alternativa sair-se com uma construção que atenda à dois lados em oposição - ou seja, a formação de compromisso.

Entende-se que as tendências a que se referiu este capítulo estão presentes na vida sexual primitiva dos seres humanos de maneira geral, tiveram expressão livre em um momento infantil do neurótico, e apenas não permanecem manifestas por efeito de recalque. Entende-se também que continuam tais tendências a demandar satisfação, e que a forma que esta satisfação assume é o sintoma descrito. Igualmente sabe-se que essa formação de sintoma se dá como uma satisfação substitutiva da libido, de maneira que este se constitua verdadeiramente como um acordo, que garanta significação suficiente e recalcamento suficiente para a pulsão sexual. Desta forma, assegura como the é possível satisfação para a pulsão, ainda que parcial e desviada, e a mantém retirada, enquanto representação, no inconsciente.

Sabe-se, desde os textos freudianos, que a retomada de organizações prégenitais e de objetos incestuosos constituem-se como ameaças de castração ao ego, que os fará impedir através do recalque que faz operar. Também se faz sabido que a libido efetivamente não se pode fazer impedida, e que o retorno do que foi recalcado, mas de maneira distorcida e que não se pode reconhecer como satisfação, é a própria estruturação do sintoma.

\section{2 - O SINTOMA E A ANGÚSTIA}

Em "A Angústia" de 1916, Freud apresenta já uma indicação da relação entre sintoma e angústia, conforme acima citado. O texto em questão aponta, sobretudo, a estreita relação entre a formação de sintomas neuróticos e a angústia. Para Freud, poderia se considerar a formação de sintomas como saída a uma situação de angústia, que de outro modo, seria inevitável. A angústia, tida cientificamente como uma reação orgânica expectante frente a uma situação de risco é atualizada na oposição entre o ego e a libido. O ego passa a encarar a exigência da libido, sua possibilidade de satisfação livre, como um perigo iminente e passa a reagir a este como a um perigo externo. A fuga e a evitação que seriam respostas adequadas a uma situação de perigo concreta são convertidas em formação de sintomas, e a angústia decorrente da libido insatisfeita faz ao sintoma sua vinculação.

Em "Inibição. Sintoma e Angústia", de 1926, Freud especifica melhor a questão da angústia relativa à formação, em um exame pormenorizado de sua relação. Quanto ao sintoma, inicia apresentando-o, categoricamente, como "um sinal ou substituto de uma satisfação jacente", que se constitui como resultante do processo de recalque. $\mathrm{O}$ ego, que é a instância que executa o recalque, pode fazê- 
lo por exigência do superego, e caracteriza-se por uma recusa em vincular-se às pulsões sexuais. A representação ideacional da pulsão sexual que é isolada pelo ego é então repelida do consciente para o inconsciente, ao que lá persiste como uma formação inconsciente.

O que se estabelece como uma questão para Freud, e que considera que havia até então ficado obscuro em sua obra, é o destino e o caminho do afeto vinculado à representação ideacional que é recalcada ao inconsciente no processo de recalque. Afirma que se pronuncia incompleta a proposição de que uma pulsão em seu caminho para uma satisfação simplesmente se converte em desprazer por força de recalque. Afirma que seria tomar a questão do ponto de vista fenomenológico, em detrimento da compreensão da questão de uma perspectiva metapsicológica.

Para Freud, a questão se esgotaria se se pudesse meramente pensar que por efeito de recalque o inconsciente se encontraria inibido de qualquer processo excitatório que se lhe tomasse e ocasionaria demandar satisfação. De qualquer forma, tal possibilidade deixa em aberto a questão que envolve a influência do ego sobre o inconsciente e seus processos.

$\mathrm{O}$ processo posto até então abre espaço para tornar à questão da estruturação de sintomas. Quanto a este, Freud afirma que se o recalque foi plenamente bem sucedido não há como apreender seu processo no decorrer de uma análise. Todavia, se o recalque se faz mal sucedido, o conteúdo pulsional retorna e se vincula a um substituto, ainda que este o seja de uma maneira reduzida e distorcida, não mais possível de ser reconhecida como uma satisfação, mas assumindo a forma de uma compulsão. O retorno do recalcado vinculado a um substituto e alcançando uma satisfação substitutiva é a própria caracterização do sintoma, como resultado em uma falha no recalque.

Ainda assim, a importância do recalque não fica menos diminuída por falhar na tentativa de suprimir o afeto da pulsão em um primeiro momento, pois que ao retornar sob a forma de uma satisfação substitutiva (sintoma), um segundo momento de recalque que se lhe opõe constitui-se como uma barreira de acesso à realidade, por ser o ego o mediador do sistema Pcpt-Cs, e à descarga pela motilidade por agir sob o princípio da realidade. Desta forma o ego, por meio do recalque, contrapõe-se ao afeto por não lhe permitir descarga por meio de ação, e ao seu representante ideacional por negar-lhe uma acesso à realidade.

Ainda no mesmo texto, Freud toma um caso de fobia do qual havia se ocupado ao longo de sua experiência profissional para ilustrar de maneira bastante didática o que exatamente constitui um sintoma neurótico o que este representa para o conflito neurótico vivido. Entendendo que o sintoma é uma formação substitutiva estruturada para dar conta de uma pulsão recalcada, Freud 
se aproveita do caso para ilustrar claramente qual é o sintoma, qual é a caraterística da pulsão e no que esta representa ameaça ao ego para dever ser recalcada.

No caso citado, o do Pequeno Hans, o menino sofria de uma fobia de cavalos que lhe impedia terminantemente de deixar sua casa. Para Freud, o seu medo exigente e angustiante de que um cavalo lhe mordesse era seu sintoma, e a incapacidade de sair à rua uma inibição constituída como evitação ao material ansiogênico.

Freud entende que a criança, em pleno e vívido conflito edipiano mantinha com seu pai uma relação ambivalente, tinha-lhe ódio por uma vertente, a este que se lhe interpunha como a um competidor, ao que, outrossim, tinha-lhe grande afeição. Supõe, portanto, que a fobia desenvolvida enquanto sintoma neurótico representava à Hans uma saída possível a esse conflito estabelecido. Por meio de recalque e deslocamento, a idéia de uma hostilidade para com seu pai foi afastada do consciente, enquanto que o afeto direcionado a um elemento substitutivo e convertido em angústia. Para Freud, o deslocamento em si, do pai para o cavalo, já constitui por si só critério suficiente para designar a fobia relatada como um sintoma neurótico. O sentimento hostil em relação ao seu pai, que, deslocado ao cavalo como objeto substitutivo, é convertido de uma tendência agressiva para medo (formação reativa) como mecanismo acessório ao recalque.

\begin{abstract}
"Ele se encontrava, à época, na atitude edipiana ciumenta e hostil em relação ao pai, a quem, não obstante - salvo até onde a mãe dele era a causa de desavença -, amava ternamente. Aqui, então, temos um conflito devido à ambivalência: um amor bem fundamentado e um ódio não menos justificável dirigidos para a mesmíssima pessoa. A fobia de 'Little Hans' deve ter sido uma tentativa de solucionar esse conflito.” (Freud, "Inibição, Sintoma e Angústia”, 1926, p. 124)
\end{abstract}

O que Freud toma, não apenas do caso Pequeno Hans mas também do caso Homem dos Lobos é que não é apenas uma tendência que é recalcada côo resultado do processo edípico. Para Freud, não foi apenas uma tendência hostil para com o pai-rival que fez necessário recalque, ou mesmo uma incômoda posição passiva em relação a este, mas também uma catexia objetal afetuosa em relação ao mãe encontrou-se como afeto recalcado, caracterizando o processo do conflito edipiano. Mais, Freud se utiliza do estudo de ambos os casos para fazer uma retificação em sua teoria. Passa a entender que a angústia observável na neurose, e que até então tomava por um efeito do ego sobre o afeto em sua defesa, é na verdade um temor diante da castração, é uma angústia realística do ego 
infantil diante da suposição de uma ameaça de castração diante da qual tem de se recolher.

O que Freud questiona é que se sabe que as três neuroses se estruturam a partir do Complexo de Édipo e tem como força motriz uma oposição egóica sustentada pelo medo da castração mas é somente na neurose fóbica é que se depreende esse medo como substrato. Se indaga, então, conforme exposto no texto em questão, é se é realmente possível fazer esse tipo de generalização a respeito do medo realístico da castração, e se essa generalização se confirma, o que faz operar o ego para subsumir o medo referido em seu funcionamento.

Atendo-se à questão das fobias animais, Freud afirma que esta se caracteriza por formar-se como defesa do ego ao contrário libidinal proveniente do inconsciente. O conteúdo em questão é referente ao complexo de Édipo, e a cessão de espaço de satisfação à tal conteúdo implica em uma vivência de um medo realístico de castração.

Outrossim, há ainda lacunas na operação descrita que faz merecer atenção. Freud afirma que o ego faz oposição ao conteúdo erótico do complexo de Édipo, mas que este conteúdo agressivo que não é de natureza erótica, libidinal. Aponta contudo que chegou a conclusão que não há, na prática, a pressão por satisfação de uma pulsão pura, distinta, mas sempre em combinação, em algum grau, das duas naturezas da pulsão. Destarte, uma catexia sádica é também composta de uma catexia libidinal e ganhará oposição egóica tanto quanto.

Freud parte do exemplo oferecido pelo caso Pequeno Hans para analisar a relação entre angústia, castração e fobia presente nas neuroses fóbicas. Neste o deslocamento do objeto de angustia de castração para o medo de ser mordido por cavalos oferece dois pontos de ganho para o ego, e se apresentam bastante condizentes com a natureza deste. Primeiramente, um conflito resultante da ambivalência em que se coloca a criança frente a seu pai é poupado por dirigir a vertente hostil para a fobia de cavalos, como um construção sintomática. Em segundo lugar acaba por representar uma vantagem ao ego, que deslocando a angústia de castração para uma fobia de um objeto outro, esterno, sua evitação se tornará menos exigente ao ego, que não se verá paralisado em suas outras funções frente a um conflito posto e uma ameaça constantemente reavivada.

Freud ressalta, contudo, que não se pode considerar uma vantagem econômica, e que fobias ou sintomas inibitórios apenas fazem por ilustrar a angustia como um sinal afetivo emitido pelo ego frente à uma ameaça de castração.

A relação à angustia de castração como formação de sintomas, assim como descrita como na neurose fóbica, também pode ser observada na neurose 
obsessiva. Nesta, o ego vivencia uma ameaça de castração advinda da relação à um superego hostil. $\mathrm{Na}$ neurose obsessiva, o superego como a figura paterna informalizada passa a representar a ameaça de castração interna, da qual uma evitação não se faz possível. Não obstante a própria ameaça internalizada torna-se vasta e dispersa, passando a ser uma angustia "social ou moral indefinida". Resta não outra alternativa a não ser pôr-se submisso às exigências superegóicas de maneira a aplacar a hostilidade do superego, e com isso evitar o percurso desencadeante da angústia. Desta forma, Freud afirma categoricamente que os sintomas são formados com a finalidade de evitar uma situação de ameaça de castração na qual a angustia seria inerente.

Faz-se observar, a partir das considerações de Freud acerca dos dois casos especificados, que o ego faz operar o recalque ante a iminência de castração. Seja a valência amorosa à mãe e a tendência hostil ao pai-rival do Pequeno Hans, seja a ambivalência de caráter sádico-anal ante seu pai para $o$ Homem dos Lobos, o que está posto como objeto do recalque são investimentos libidinais que trazem consigo, em algum momento, uma ameaça de castração.

Sabe-se, também, que a angústia constitui-se como um sinal afetivo de alerta diante de uma situação de risco ao ego. E deve-se considerar que é um risco de grande relevância para o ego uma situação que traz em si uma ameaça de castração.O que se depreende da presente articulação é a angústia de castração como força motriz do recalque, é o recalque ocorrendo como uma reação à ameaça de castração sinalizada pela angústia.

Para Freud, a angustia se apresenta então como uma reação a uma situação muitas vezes experimentada, a de castração. Desde a mais tenra idade, há registros psíquicos dessa natureza, como a perda do seio materno e a separação das fezes. Faz avançar então o conceito de angustia, que até então era tido como um sinal afetivo de perigo, de ameaça de castração, para a compreensão da angustia como uma reação à uma situação real de castração.

Freud toma a questão da angústia como ponto importante nas neuroses e se propõe deter-se nela de maneira a esclarecer suas contradições. Para Freud, a angustia é um estado afetivo, e enquanto sentimento apresenta o caráter de desprazer. Freud afirma que não se trata de um desprazer genérico e que tampouco todo desprazer é o sentimento de uma angústia, mas que esta caracteriza por um desprazer particular.

Freud descreve a angustia como "um estado especial de desprazer com atos de descarga ao longo de trilhas específicas". Afirma que há, porém, de se buscar ainda uma origem histórica para a angustia. Freud diz que esta é o momento do nascimento, e tinham como finalidade, em função das inervações motoras que são ativadas no desencadeamento do processo de angustia, a própria 
preparação do organismo humano para a respiração e para a vida. O que faz com que a angústia seja uma questão é o fato dela surgir diante de uma situação de perigo, mesmo quando já há muito deixou de ser a resposta mais adequada. $\mathrm{O}$ fato é que ela passa a se apresentar como uma evitação pode ser empreendida com evitação da situação ameaçadora mesma.

Para Freud, a angústia aparece como uma reação ao objeto perdido, enquanto que este, em um momento primitivo, representa a provisão e a satisfação das necessidades. Destarte, a angustia é a reação ao acúmulo de estímulos que não alcançam satisfação e que acabam por ganhar descarga sob a forma específica da inervação motora da angustia, quando da compreensão que é um objeto externo que media essa relação do estímulo à satisfação, a angustia é deslocada para a própria ausência do objeto que lhe representa satisfação e sem o qual não se pode tê-la.

"A imagem mnêmica que a criança tem da pessoa pela qual ela sente anseio é sem dúvida intensamente catexizada, provavelmente de forma alucinatória inicialmente. Mas isto não tem qualquer efeito, parecendo agora que o anseio se transforma em angústia." (Freud, "Inibição, Sintoma e Angústia", 1926, p. 160)

A primeira separação angustiante é da mãe provedora por ocasião do nascimento. Também a angústia referente à ameaça de castração é tido como a angustia de separação de seus órgãos genitais e da consequente perda da possibilidade de eventualmente tornar a unir-se à mãe perdida no ato da copulação. Com a passagem pelo complexo de Édipo e a internalização da figura castradora sob a forma de superego, há uma despersonalização do agente castrador e uma consequente angústia de castração desenvolvido em angústia moral e social.

Freud afirma ainda que a angústia é um processo que toma lugar no ego, e todos os momentos da angústia nele coexistem. Sobre isso, Freud afirma:

"Assim o perigo de desamparo psíquico é apropriado ao perigo de vida quando o ego do indivíduo é imaturo; o perigo da perda do objeto, até a primeira infância, quando ele ainda se acha na dependência de outros, o perigo de castração, até a fase fálica; e o medo do seu superego, até o período de latência. Não obstante, todas essas situações de perigo e determinantes de angústia podem resistir lado a lado fazer com que o ego a elas reaja com angústia num período ulterior ao apropriado; ou além disso, várias delas podem entrar em ação ao mesmo tempo.” (Freud, 1926, Inibição, Sintoma e Angústia, pág. 162) 
Ainda, Freud é bastante categórico em afirmar que a angústia e a forma que esta toma tem estreita relação com a neurose desenvolvida, que a angústia de castração é "a única força motora dos processos defensivos que conduzem à neurose". Afirma que mesmo a mulher vivencia a angústia de castração não como a perda do objeto, mas de perder o amor do objeto, que esta relação à castração para a mulher representa o mesmo papel na formação das fobias e o temor às exigências superegóicas como formação das neuroses obsessivas.

É a partir do percurso percorrido no referido texto, brevemente aqui reproduzido, que Freud finalmente lança-se a estabelecer uma clara e estreita relação entre a angústia e a formação de sintomas. Para Freud, não se pode pensar na angústia que não seja em relação a uma situação de perigo, e refere-se a situação de perigo própria da angústia realística da castração, em todo seu desenvolvimento ontogenético explicado anteriormente. É na relação às exigências inconscientes, no caráter premente da vida pulsional, que a ameaça de castração, que a ameaça de perda do objeto ou de seu amor se afigura. É em relação ao desenvolvimento de um sentimento hostil e ambivalente para com o pai/rival, e o amor genital para com a mãe que constitui o conflito para o qual o sintoma se constitui como uma saída, um acordo entre as partes em conflito. $\mathrm{O}$ ego fica desamparado diante do conflito, tal qual na situação do nascimento, o qual Freud aponta ser o determinante original da angústia. $\mathrm{O}$ sintoma constitui a evitação da ameaça.

"Visto que remetemos a geração da ansiedade a uma situação de perigo, preferiremos dizer que os sintomas são criados a fim de remover o ego de uma situação de perigo. Se se impedir que os sintomas sejam formados, o perigo de fato se concretiza; isto é, uma situação análoga ao nascimento se estabelece, na qual o ego fica desamparado em face de uma exigência instintual constantemente crescente - o determinante mais antigo e original da ansiedade.” (Freud, 1926, Inibição, Sintoma e Angústia, pág. 168)

Em “A Dissolução do Complexo de Édipo", de 1924, a relação entre a angústia de castração e a formação de sintomas é afirmada mais categoricamente, e mais explicitamente exposta. Neste, Freud coloca que o Complexo de Édipo constitui-se como "o fenômeno central do período sexual da primeira infância" (Freud, 1924, “A Dissolução do Complexo de Édipo", pág. 217), e é através deste que se faz possível estabelecer a própria relação da angústia com a formação de sintomas. Muito já se abordou, neste trabalho, a respeito do caminho da libido até sua frustração e consequente regressão. igualmente se mencionou o fato de a libido regredida adotar objetos incestuosos, os quais fazem merecer o efeito de 
recalque por parte do ego. Destarte, o que se apresenta como questão premente é: - o que há na retomada regressiva da libido, na escolha objetal de natureza edípica, que se apresenta como ameaça ao ego a ponto de merecer desse um movimento de recalque?

Não se pode negar a sensação de obviedade perante à indagação, posto a própria interdição introjetada em cada um de nós, mas entendendo a natureza da libido, faz-se necessário perguntar a respeito do que se configura como uma ameaça a ponto de ser recalcada, a ponto de ter seu retorno possível apenas através da emergência distorcida e irreconhecível que é o sintoma.

No referido texto, Freud lança-se a explanar com precisão as condições em que o amor incestuoso implica em uma inevitável ameaça de castração, de maneira que um amor narcísico pelo objeto de ameaça (o pênis para os meninos, o próprio amor para as meninas) põe-se em posição conflitiva ao referido investimento libidinal.

\footnotetext{
"Se a satisfação do amor no campo do complexo de Édipo deve custar à criança o pênis, está fadado a surgir um conflito entre seu interesse narcísico nessa parte de seu corpo e a catexia libidinal de seus objetos parentais. Nesse conflito, triunfa normalmente a primeira dessas forças: o ego da criança volta as costas ao complexo de Édipo.” (Freud, 1924, “A Dissolução do Complexo de Édipo, pág. 201)
}

O texto em questão tece considerações acerca de um tema já abordado neste trabalho, o do desenvolvimento da libido até a fase genital, contemporânea do Complexo de Édipo, e todas as suas vicissitudes até o recalque. Contudo, este traz um aspecto extra que se assoma ao tema e é a este pertinente, pois que aponta o que seria a constituição de uma ameaça de castração. Parece ser em pequenas historietas, aparentemente sem importância que esta se estabelece, através de representações simbólicas a posteriori de castração e que sustentam o próprio Complexo de Castração. Freud coloca que é comum à fase fálica a criança brincar com seus genitais, extrair destes o prazer que sua manipulação oferece. Descobre a criança, todavia, não apenas o prazer inerente à manipulação de seus genitais, mas também que os adultos desaprovam tal atitude e não pouparão reprimendas ao ato, tome esta a forma que tomar. A reprimenda ao ato masturbatório é a princípio desacreditada, mas a constatação da diferença, a realização do órgão sexual feminino, tomado como a ausência do pênis dá credibilidade à reprimenda e confere a esta o status de ameaça de castração, agora levada bastante a sério. Freud pontua, entretanto, que a manipulação dos genitais está bastante longe de exiguir a atividade sexual do infante, esta serva apenas de descarga genital de uma excitação constituída na relação aos pais. A 
relação em questão representa para a criança duas possibilidades de satisfação, ainda que por uma noção bastante vaga de uma relação sexual satisfatória: a de assumir uma postura masculina, tal qual o pai, e desta maneira amar a sua mãe e tomar o pai como um estorvo aos seus intentos; e de pôr-se no lugar da mãe, e se deixar ser amado pelo pai. Para o menino, qualquer uma das posições é seguida por uma ameaça de castração.

“Agora, porém, sua aceitação da possibilidade de castração, seu reconhecimento de que as mulheres eram castradas, punha fim às duas maneiras possíveis de obter satisfação do complexo de Édipo, de vez que ambas acarretavam a perda de seu pênis - a masculina como uma punição resultante e a feminina como precondição.” (Freud, “a Dissolução do Complexo de Édipo", 1924, p. 221)

O que se estabelece neste ego infantil é um conflito posto entre uma parte da libido investida nos pais e o interesse narcísico de manter seu pênis. Freud não hesita em afirmar, contudo, que no referido, inevitavelmente, o interesse narcísico no próprio corpo é preferido em detrimento da catexia libidinal ameaçadora, cuja representação é então recalcada. As formações subsequentes ao processo de recalque do investimento libidinal nos pais, como a introjeção da autoridade do pai, formando o superego; e a dessexualização do investimento, que é convertido em afeição e caracterizará o período de latência, esta não correspondem diretamente ao tema central deste trabalho, ao que esta não mais se delongará na questão.

Neste ponto do trabalho faz-se necessário apontar uma lacuna na apresentação do tema, pois que pouco se abordou da relação entre as produções sintomáticas e a ameaça de castração que a valência edípica representa. Freud bem aponta que há mesmo uma obscuridade referente à castração na mulher. Não é, certamente, um processo idêntico ao masculino, pela própria condição anatômica que o precede.

A menina pouco pode sustentar seu clitóris no lugar de um pênis, e ante qualquer comparação esta sente que foi prejudicada, que a ela lhe foi cometida uma injustiça por não possuir um pênis tal qual o observado. Até acredita por um tempo, como um momento de negação à castração, que o tempo lhe conferirá um órgão de igual proporção. Mais, acredita que possuiu um pênis tal qual o observado, e que o perdeu. Deste modo a castração é também presente como acontecimento psíquico na vida menina, não como ameaça, mas como fato consumado. A criança procurará uma compensação pelo que perdeu.

“A renúncia ao pênis não é tolerada pela menina sem alguma tentativa de compensação. Ela desliza - ao longo da linha de uma equação simbólica, 
poder-se-ia dizer - do pênis para um bebê. Seu complexo de Édipo culmina em um desejo, mantido por muito tempo, de receber do pai um bebê como presente — dar-lhe um filho". (Freud, "A Dissolução do Complexo de Édipo, 1924, p. 223)

O que se depreende do exposto é que a universalidade do Complexo de Édipo implica em também uma universalidade do complexo de castração, e que esta não será tolerada por qualquer neurótico como expensas à sua satisfação livre. Outrossim, não pode fazer desaparecer aquilo que recalcou, e os conteúdos de natureza edípica recalcados demandam sua satisfação. Isto posto, não seria mais do que redundante retomar a tão trabalhada importância do sintoma como um acordo formado entre as partes em conflito. O sintoma constitui-se como "tábua de salvação", considerando as circunstâncias do conflito em questão, e será sustentado ferrenhamente pelo neurótico.

\section{CONCLUSÃO}

Sabemos que a angústia é a mola propulsora do recalque. Ainda que a angústia seja terrorífica ao ego e tende a ser evitada, esta se constitui de valor inestimável para o neurótico, pois que mitiga a própria realidade da castração. Mais, constituída como um sinal afetivo de perigo iminente, de um risco que é uma ameaça mesma de castração, permite ao ego que se defenda disso através do processo de recalque. Antes a angústia proveniente da ameaça de castração do que a castração em si, esta seria uma formulação que expressaria o lugar da angústia para o neurótico.

$\mathrm{O}$ que sabemos é que estando presente a angústia, esta como sinal de perigo iminente, o ego pode proceder com o recalque de maneira a defender-se do que se lhe constitui como ameaça. Mas em que subsiste essa ameaça de que o ego tem de defender-se?

A castração. O percurso deste trabalho permite afirmar que é insuportável para o neurótico lidar com aquilo que possa lhe representar castração. Através do texto "Análise Terminável e Interminável" de 1937, o conceito de Complexo de Castração (ou "Repúdio à Feminilidade", como Freud afirma preferir) dá a idéia exata da conclusão a que se chegou com este trabalho. $\mathrm{O}$ que Freud afirma no citado texto como referente ao contexto de análise pode ser facilmente transposto à própria estruturação da neurose. Neste, é evidenciado a insuportabilidade do neurótico frente ao assunto de sua castração. Bastante indistintamente, o que se obtém como resistência última em uma análise, seja para homens ou mulheres, é o ponto limite da castração. Deve-se considerar as 
diferenças fundamentais entre os gêneros na forma que o Complexo de Castração assume, é evidente. Enquanto que todo esforço feminino parece se sustentar no desejo mais íntimo e arraigado de recuperar seu pênis perdido, e encontra neste seu limite de análise, o homem alcança seu próprio limite quando deve abrir mão de fazer proliferar representações de feminilidade e castração pelos campos de sua vida ativa e produtiva.

O que se extrai disso, para o tema específico desse trabalho, é que o horror à castração estabelece-se como o elemento mais basilar da vida do neurótico. Este trabalho ousa conferir ao sintoma o caráter de inevitável, e é de se perguntar qual é o sentido de tal afirmação, bem como em quê esta se sustenta.

Primeiramente se deve afirmar, uma vez o tema da libido suficientemente explorado, que às pulsões sexuais apenas resta a satisfação. Não há outro destino, final e permanente que se possa ter as pulsões sexuais. Três dos destinos apontados por Freud em "As Pulsões e Seus Destinos", sublimação, transformação em seu contrário e orientação contra a própria pessoa são apenas formas desviadas e distorcidas da satisfação inevitável da pulsão. quanto ao quarto destino da pulsão, o recalque, este teve maior ênfase nesse trabalho, e a partir deste se faz possível afirmar que o retorno do recalcado é também inevitável, e que o recalque apenas age no sentido de assegurar que este adote uma forma que o ego possa ignorar seu conteúdo.

Mais, este trabalho possibilitou igualmente arguir quanto à inevitabilidade da angústia, enquanto angústia expectante que emerge ante uma situação de risco. E quanto ao risco e sua configuração, quanto à castração que tanto é repudiada pelo ego, assuma a forma que assumir, é também universal e inevitável. A angústia é inevitável porque assim o é o horror à castração, assim o é o repúdio à feminilidade.

Mas em quê, exatamente, a inevitabilidade do retorno do recalcado e da angústia, implicam em uma inevitabilidade do sintoma? Faz-se possível saber através deste trabalho que o sintoma representa para o neurótico uma construção única, que torna perfeitamente possível coadunar o efeito de recalque e a satisfação do conteúdo recalcado, de natureza edípica. Através do sintoma tornase possível ao neurótico negar a castração, fingir que esta não existe, e assegurar ao menos um excerto de satisfação sexual de natureza edípica sem estar esta associada á uma angústia expectante de castração. Destarte, e em função das inevitabilidades apresentadas, faz-se possível afirmar o sintoma inevitável, este na qualidade de produção através da qual o neurótico faz sumir a ameaça de castração e garantir a si o mínimo de satisfação a qual não poderia evitar. 


\section{REFERÊNCIAS BIBLIOGRÁFICAS}

FREUD, S.. Os Caminho da Formação dos Sintomas (1916a). In: .Pequena Coleção das Obras de Freud. Imago, Rio de Janeiro, 1976, Livro 23.

O Estado Neurótico Comum (1916b). In: .Pequena

Coleção das Obras de Freud. Imago, Rio de Janeiro, 1976, Livro 23.

. A Ansiedade (1916c). In:

.Pequena Coleção das Obras de

Freud. Imago, Rio de Janeiro, 1976, Livro 23.

FREUD, S.. Uma Teoria Sexual (1905). In:

Sigmund Freud. Delta, Rio de Janeiro, 1958, Volume V . Os Instintos e seus Destinos (1915a). In: .Obras Completas de mund Freud. Delta, Rio de Janeiro, 1958, Volume V.

de Sigmund Freud. Delta, Rio de J
. A Repressão (1915b). In:

Freud. Delta, Rio de Janeiro, 1958, Volume V.

.Obras Completas de Sigmund . O Inconsciente (1915c). In:

Freud. Delta, Rio de Janeiro, 1958, Volume V

.Obras Completas de Sigmund

FREUD, S.. Meus Pontos de Vista Sobre o Papel Desempenhado pela

Sexualidade na Etiologia das Neuroses (1906). In: .Edição Standard

Brasileira das Obras Psicológicas Completas de Sigmund Freud. Imago, Rio de Janeiro, 1987, v.VII

. Recordar, Repetir e Elaborar(1914). In: .Edição Standard

Brasileira das Obras Psicológicas Completas de Sigmund Freud. Imago, Rio de Janeiro, 1987, v.XII.

. Caráter e Erotismo Anal (1908) In: .Edição Standard

Brasileira das Obras Psicológicas Completas de Sigmund Freud. Imago, Rio de Janeiro, 1987, v. IX.

. Fantasias Histéricas e sua Relação com a Bissexualidade (1908). In: .Edição Standard Brasileira das Obras Psicológicas Completas de Sigmund Freud. Imago, Rio de Janeiro, 1987, v. IX.

A Cabeça da Medusa (1922). In: .Edição Standard

Brasileira das Obras Psicológicas Completas de Sigmund Freud. Imago, Rio de Janeiro, 1987, v. XVIII.

(1916). In:

Algumas Idéias sobre Desenvolvimento e Regressão - Etiologia

Completas de Sigmund Freud. Imago, Rio de Janeiro, 1987, v. XVI.

. O Sentido do Sintoma (1916). In: .Edição Standard

Brasileira das Obras Psicológicas Completas de Sigmund Freud. Imago, Rio de Janeiro, 1987, v. XVI 
Sobre o Início do Tratamento (1913). In: .Edição

Standard Brasileira das Obras Psicológicas Completas de Sigmund Freud. Imago, Rio de Janeiro, 1987, v. XII.

. O Desenvolvimento da Libido e as Organizações Sexuais (1916). In: _.Edição Standard Brasileira das Obras Psicológicas Completas de Sigmund Freud. Imago, Rio de Janeiro, 1987, v. XVI. . Algumas Consequências Psíquicas da Distinção Anatômica entre os Sexos (1925), In: _.Edição Standard Brasileira das Obras Psicológicas Completas de Sigmund Freud. Imago, Rio de Janeiro, 1987, v.XIX.

. A Dissolução do Complexo de Édipo (1924). In: .Edição

Standard Brasileira das Obras Psicológicas Completas de Sigmund Freud. Imago, Rio de Janeiro, 1987, v. XIX . Inibição, Sintoma e Ansiedade (1926). In: .Edição

Standard Brasileira das Obras Psicológicas Completas de Sigmund Freud. Imago, Rio de Janeiro, 1987, v. XX. . Análise Terminável e Interminável (1937). In: .Edição

Standard Brasileira das Obras Psicológicas Completas de Sigmund Freud. Imago, Rio de Janeiro, 1987, v. XXIII. . O Retorno do Reprimido In: moisés e o Monoteísmo (1939). In: .Edição Standard Brasileira das Obras Psicológicas Completas de Sigmund Freud. Imago, Rio de Janeiro, 1987, v. XXIII. KAUFMANN, P. Dicionário Enciclopédico de Psicanálise - o legado de Freud e Lacan. Jorge Zahar Editor, Rio de Janeiro,1996. 